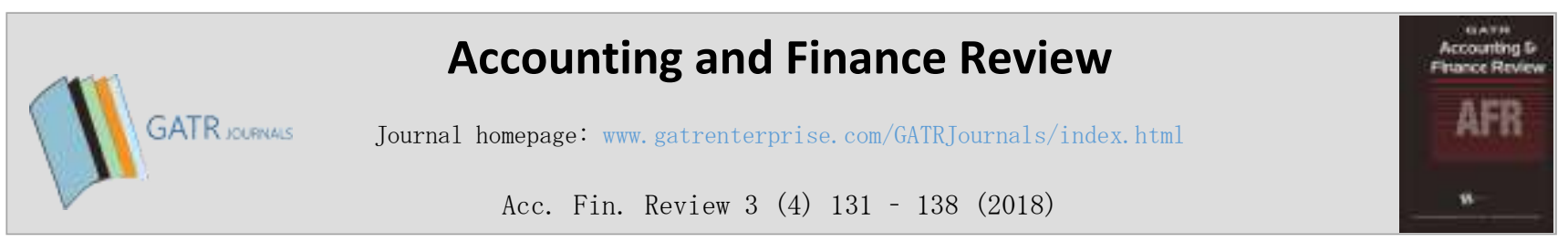

\title{
Capital Policy on Firm's Profitability: A Case of the Thai Agro and Food Industry
}

\author{
Sareeya WICHITSATHIAN \\ Institute of Social Technology, Suranaree University of Technology, Nakhon Ratchasima 30000, Thailand
}

\begin{abstract}
Objective - The objectives of this research include: (1) to identify working capital investment policy and working capital financing policy, (2) to study the effect of working capital investment policy on profitability, and (3) to study the effect of working capital financing policy on profitability.

Methodology/Technique - 41 firms in the agro-food industry listed on the Stock Exchange of Thailand are examined in this study. Secondary data was collected and analyzed within a 5-year period between 2013-2017.

Findings - The results show that the most frequently employed working capital investment policy is the aggressive approach $(46.30 \%)$, and the most frequently employed financial policy is the moderate approach $(82.90 \%)$. According to the inferential statistics, it is concluded that: (1) profitability is significantly affected by the choice of working capital investment policy and a moderate investment policy results in the greatest profitability, and (2) profitability is not affected by the choice of working capital financing policy.

Novelty - As a result, firms should focus on the selection of a moderate working capital investment policy when seeking to maximize profits. On the other hand, any type of working capital financing policy (aggressive, conservative, or moderate approach) is appropriate.
\end{abstract}

Type of Paper: Empirical.

Keywords: Working Capital Policy; Profitability; Agro and Food Industry; Thailand.

JEL Classification: M10, M40, M41.

\section{Introduction}

Working capital is essential to businesses for generating revenue (Koh et al., 2014) and making important financial decisions (Pandey, 2000). Working capital management consists of managing current assets and current liabilities and plays an important role in determining profitability (Jayarathne, 2014; Smith, 1980). The practice of working capital management aims to provide companies with sufficient cash flow for normal operation and enable them to meet their short-term commitments (Mansoori \& Muhammad, 2012).

\footnotetext{
* Paper info: Revised: November 5, 2018

Accepted: December 11, 2018

* Corresponding author: Sareeya Wichitsathian

E-mail: sareeya@sut.ac.th

Affiliation: Institute of Social Technology, Suranaree University of Technology, Thailand
} 
Working capital policy may be described as either (1) an investment policy, which deals with investment in current assets or (2) a financing policy, which deals with financing for current assets (Koh et al., 2014; Nazir \& Afza, 2009). Both policies may be described as either aggressive, moderate, or conservative (Watson $\&$ Head, 2012). The type of policy selected is dependent upon the amount of risk incurred and the potential for profitability (Koh et al., 2014; Brigham \& Houston, 1998). The most effective working capital management depends upon the correct working capital policy for a firm. As a result, financial managers should focus their efforts on choosing the most appropriate working capital policy in order to maximize profitability.

Recent studies focus on the correlation between a company's approach to working capital policy and its profitability, however, sub-policy can only be defined as aggressive and conservative (Sudiyatno et al., 2017; Mwangi et al., 2014; Javid \& Zita, 2014). This study aims to determine three sub-policies and prove that the selection of different working capital policies can lead to an increase in profitability. The study also investigates the correlation between profitability and working capital policies chosen by managers in the agro-food industry on the Stock Exchange of Thailand.

\section{Literature Review}

Working capital management is the management of current assets and current liabilities. It has two main objectives: (1) to increase the profitability of a company, and (2) to ensure sufficient liquidity to meet shortterm obligations at maturity (Pass \& Pike 1984). Determining working capital policy is an important part of working capital management. There are two questions that should be asked: (1) how much working capital is sufficient for the operation? and (2) which funding sources should be used for working capital? Therefore, working capital policy is divided into two main policies, namely: working capital investment policy and working capital financing policy (Koh et al., 2014; Brigham \& Houston, 1998).

Working capital investment policy may be described as one of three types: (1) an aggressive working capital investment policy, which involves low liquidity, high risk and high profit that reduces the holding of current assets in order to lower the cost of holding current assets, (2) a conservative working capital investment policy, which is defined by high liquidity, low risk and low profit which focuses on investing in large amounts of current assets to ensure sufficient working capital, and (3) a moderate working capital investment policy which is invested in current assets in proportion to the need to use working capital, resulting in moderate liquidity, risk and profitability (Hassani \& Tavosi, 2014; Nazir \& Afza, 2009; Weinraub \& Visscher, 1998).

The type of working capital investment policy can be measured by comparing the total current assets to total assets (Adam et al., 2017; Sudiyatno et al., 2017; Nabi et al., 2016; Nazir \& Afza, 2009). A higher ratio indicates a more conservative working capital investment policy (more than 0.5 ) while lower ratios indicate a more aggressive policy (less than 0.5) (Adam et al., 2017). Hence, a ratio close to 0.5 indicates a moderate working capital investment policy.

Working capital financing policy is a financing source for current assets which can be divided into three sub-policies, (1) aggressive working capital financing policy, which focuses on short-term debt for current assets. This creates lower financial costs than long-term debt sources and helps a company achieve higher profitability. (2) Conservative working capital financing policy, which focuses on long-term debt to reduce the risk of failing to pay according to the specified period. However, the high cost of long-term debt reduces profitability. (3) moderate working capital financing policy, which is a coherent management principle between the source of capital and capital used. This leads to moderate profitability. (Hassani \& Tavosi, 2014; Nazir \& Afza, 2009; Weinraub \& Visscher, 1998).

The working capital financing policy can be measured by the ratio of total current liabilities to total assets (Adam et al., 2017; Sudiyatno et al., 2017; Nabi et al., 2016; Nazir \& Afza, 2009). In this way, a higher ratio indicates an aggressive working capital financing policy (more than 0.5), and a lower ratio suggests a 
conservative working capital financing policy (less than 0.5) (Adam et al., 2017). Hence, a ratio close to 0.5 reveals a moderate working capital financing policy.

In the empirical literature reviews, there are many studies on working capital policy and profitability. The study of Niresh (2012) in Sri Lanka shows that working capital investment policy has a positive relationship with return on assets, and working capital financing policy has negative relationship with return on assets. This means that a company can increase its profitability by adopting a conservative working capital investment policy and a conservative working capital financing policy, according to Jordan of Shubiri (2011) and Sudiyatno et al. (2017). Additionally, research conducted in Kenya by Mwangi et al. (2014) shows that working capital investment policies and working capital financing policies have a positive relationship with return on assets. That study concludes that conservative working capital investment policies and aggressive working capital financing policies lead to higher profitability. As the previous studies focus on relationship between the working capital policy and the profitability by using the relationship direction to determine subpolicy, only two sub-policies can be defined (aggressive and conservative approaches). The research questions in this study therefore are: (1) how to determine the three sub-policies? and (2) can profitability be enhanced by the use of a moderate working capital policy?

The proposed hypotheses are as follows:

H1: The selection of different working capital investment policies has a significant effect on profitability.

H2: The selection of different working capital financing policies has a significant effect on profitability.

\section{Research Methodology}

\subsection{Data and Variables}

The initial target population of the study included 50 companies in the agro-food industry listed on the Stock Exchange of Thailand. After excluding companies which have been listed for less than five years, 41 companies remained in the study. This study uses secondary data which had been aggregated from 2013 to 2017.

The dependent variable of this study is firm profitability which is measured by return on asset (ROA) and can be calculated from net profit divided by total assets (Hassan et al., 2017). The independent variable in this study is the working capital policy, consisting of both investment and financing policy.

\subsection{Statistical Method}

The first step of the study is to determine the type of policy by performing a One-Sample $\mathrm{T}$ Test. Assuming that the working capital financing policy value ranges between 0 and 1 , the values of the dependent variable is compared with a perfectly moderate value of 0.5 . The results are classified into three different categories as follows:

1. If the ratio is below the moderate value of 0.5 , and there is a statistically significant difference between the two, it will be classified as an aggressive working capital investment policy with a conservative working capital financing policy.

2. If the ratio is above the moderate value of 0.5 , and there is a statistically significant difference between the two, it will be classified as a conservative working capital investment policy with an aggressive working capital financing policy. 
3. If there is no statistically significant difference between the moderate value $(0.5)$ and the calculated policy value, the policies will be categorized as a moderate approach in both the working capital investment and financing policies.

4.

The second step is to test the hypothesis using a One-way ANOVA. The dependent variable of this study is the ratio of return on assets (ROA). The independent variable of this study is working capital policy which is determined in the first step.

\section{Analysis and Results}

The classification criteria for working capital policy are shown in Table 1. The results show that policy values between 0.00 and 0.40 exhibit a statistically significant difference. The moderate values of 0.50 may be classified as an aggressive working capital investment policy and a conservative working capital financing policy. Policy values between 0.60 to 1.00 exhibit sufficient statistical difference. The moderate values may be classified as the conservative working capital investment policy and aggressive financing policy. Values between 0.41 to 0.59 fail to exhibit a statistically significant difference from 0.50 and are classified as a moderate approach.

Table 1. The classification of working capital policy

\begin{tabular}{|l|l|l|l|l|l|l|l|}
\hline \multicolumn{4}{|l|}{ Working capital investment policy } & \multicolumn{4}{l|}{ Working capital financing policy } \\
\hline Policy Value & T & Df & Sig. & Policy Value & T & Df & Sig. \\
\hline $0.00-0.40$ (AIP) & -12.289 & 18 & $0.000 * *$ & $0.00-0.40($ CFP) & -15.674 & 33 & $0.000 * *$ \\
\hline $0.41-0.59$ (MIP) & -1.137 & 14 & 0.274 & $0.41-0.59(\mathrm{MFP})$ & -2.333 & 3 & 0.102 \\
\hline $0.60-1.00$ (CIP) & 8.435 & 6 & $0.000^{* *}$ & $0.60-1.00(\mathrm{AFP})$ & 13.000 & 2 & $0.006^{* *}$ \\
\hline
\end{tabular}

Note1: AIP=Aggressive working capital investment policy, $\mathrm{MIP}=$ Moderate working capital investment policy, $\mathrm{CIP}=$ Conservative working capital investment policy, $\mathrm{AFP}=$ Aggressive working capital financing policy, $\mathrm{MFP}=$ Moderate working capital financing policy, and $\mathrm{CFP}=$ Conservative working capital financing policy.

Note2: ** Significant at $\mathrm{P}<0.01, *$ Significant at $\mathrm{P}<0.05$

Table 2. The working capital policy of the agro and food industry on the stock exchange of Thailand

\begin{tabular}{|c|c|c|c|c|c|c|c|c|c|c|c|c|c|}
\hline \multirow[b]{2}{*}{ Company } & \multirow{2}{*}{$\begin{array}{l}\text { ROA } \\
(\text { Mean } \%)\end{array}$} & \multicolumn{6}{|c|}{ Working capital investment policy } & \multicolumn{6}{|c|}{ Working capital financing policy } \\
\hline & & $\begin{array}{c}201 \\
7\end{array}$ & $\begin{array}{c}201 \\
6\end{array}$ & $\begin{array}{c}201 \\
5\end{array}$ & $\begin{array}{c}201 \\
4\end{array}$ & $\begin{array}{c}201 \\
3\end{array}$ & $\begin{array}{c}\text { Mea } \\
\mathbf{n}\end{array}$ & $\begin{array}{c}201 \\
7 \\
\end{array}$ & $\begin{array}{c}201 \\
6\end{array}$ & $\begin{array}{c}201 \\
5\end{array}$ & $\begin{array}{c}201 \\
4\end{array}$ & $\begin{array}{c}201 \\
3\end{array}$ & $\begin{array}{c}\text { Mea } \\
\text { n }\end{array}$ \\
\hline 1 & 21.54 & $\mathrm{C}$ & M & M & M & M & M & $\mathrm{C}$ & $\mathrm{C}$ & $\mathrm{C}$ & $\mathrm{C}$ & $\mathrm{C}$ & $\mathrm{C}$ \\
\hline 2 & 21.25 & A & A & M & M & M & M & $\mathrm{C}$ & $\mathrm{C}$ & $\mathrm{C}$ & $\mathrm{C}$ & $\mathrm{C}$ & $\mathrm{C}$ \\
\hline 3 & 18.94 & $\mathrm{M}$ & M & M & M & M & M & $\mathrm{C}$ & $\mathrm{C}$ & $\mathrm{C}$ & $\mathrm{C}$ & $\mathrm{C}$ & $\mathrm{C}$ \\
\hline 4 & 18.87 & $\mathrm{C}$ & $\mathrm{C}$ & M & $\mathrm{C}$ & $\mathrm{C}$ & $\mathrm{C}$ & $\mathrm{C}$ & $\mathrm{C}$ & $\mathrm{C}$ & $\mathrm{C}$ & $\mathrm{C}$ & $\mathrm{C}$ \\
\hline 5 & 18.21 & M & A & M & $\mathrm{M}$ & M & M & $\mathrm{C}$ & $\mathrm{C}$ & $\mathrm{C}$ & $\mathrm{C}$ & $\mathrm{C}$ & $\mathrm{C}$ \\
\hline 6 & 17.62 & $\mathrm{C}$ & $\mathrm{C}$ & $\mathrm{C}$ & $\mathrm{C}$ & A & $\mathrm{C}$ & $\mathrm{C}$ & $\mathrm{C}$ & $\mathrm{C}$ & $\mathrm{C}$ & $\mathrm{C}$ & $\mathrm{C}$ \\
\hline 7 & 17.12 & M & $\mathrm{M}$ & M & $\mathrm{M}$ & M & M & $\mathrm{C}$ & $\mathrm{C}$ & $\mathrm{C}$ & $\mathrm{C}$ & A & $\mathrm{C}$ \\
\hline
\end{tabular}




\begin{tabular}{|c|c|c|c|c|c|c|c|c|c|c|c|c|c|}
\hline 8 & 14.74 & M & M & M & M & $\mathrm{M}$ & M & A & M & A & A & A & A \\
\hline 9 & 13.47 & M & M & M & C & C & M & C & C & C & C & C & C \\
\hline 10 & 11.61 & A & A & A & A & A & A & C & C & C & C & C & C \\
\hline 11 & 10.69 & C & C & C & C & C & C & M & A & A & M & A & A \\
\hline 12 & 10.43 & M & M & $\mathrm{M}$ & M & A & M & C & C & C & C & C & C \\
\hline 13 & 10.34 & A & A & A & A & A & A & C & C & C & M & C & C \\
\hline 14 & 10.32 & A & M & M & $\mathrm{M}$ & M & M & C & C & C & C & C & C \\
\hline 15 & 9.89 & A & A & A & A & A & A & C & C & $\mathrm{C}$ & C & M & C \\
\hline 16 & 9.75 & A & A & A & A & A & A & C & C & C & C & C & C \\
\hline 17 & 9.74 & A & A & A & A & A & A & M & M & M & M & M & M \\
\hline 18 & 9.24 & A & A & A & A & A & A & C & C & C & C & C & C \\
\hline 19 & 9.08 & M & $\mathrm{M}$ & M & $\mathrm{M}$ & M & M & C & C & M & C & C & C \\
\hline 20 & 8.65 & C & C & C & C & C & C & C & C & C & C & C & C \\
\hline 21 & 6.76 & M & M & M & A & A & M & C & C & C & C & C & C \\
\hline 22 & 6.75 & A & A & A & $\mathrm{M}$ & M & A & $\mathrm{C}$ & C & C & C & M & C \\
\hline 23 & 6.73 & A & A & A & A & A & A & C & C & C & C & C & C \\
\hline 24 & 6.73 & C & C & C & $\mathrm{C}$ & M & C & C & C & $\mathrm{C}$ & M & M & C \\
\hline 25 & 6.66 & M & M & M & $\mathrm{M}$ & $\mathrm{M}$ & M & C & C & C & C & M & C \\
\hline 26 & 6.34 & A & A & A & A & A & A & C & C & C & C & C & C \\
\hline 27 & 6.19 & A & A & A & A & M & A & $\mathrm{C}$ & M & $\mathrm{C}$ & M & A & M \\
\hline 28 & 6.15 & A & A & A & A & A & A & C & C & $\mathrm{C}$ & C & C & C \\
\hline 29 & 5.86 & A & A & A & A & A & A & C & C & C & C & C & C \\
\hline 30 & 3.75 & M & M & M & M & $\mathrm{M}$ & M & M & M & M & M & A & $\mathrm{M}$ \\
\hline 31 & 3.67 & A & A & A & A & A & A & C & C & C & C & C & C \\
\hline 32 & 2.98 & A & A & A & A & A & A & M & C & C & C & C & C \\
\hline 33 & 2.40 & $\mathrm{C}$ & C & C & $\mathrm{C}$ & C & C & C & C & C & M & C & C \\
\hline 34 & 2.20 & A & A & A & A & A & A & C & C & C & C & C & C \\
\hline 35 & 2.08 & A & C & M & $\mathrm{M}$ & $\mathrm{M}$ & M & M & $\mathrm{C}$ & C & C & C & C \\
\hline 36 & 1.68 & M & M & M & $\mathrm{M}$ & M & M & M & M & M & C & M & $\mathrm{M}$ \\
\hline 37 & 1.51 & A & A & A & A & A & A & C & M & C & C & C & C \\
\hline 38 & 1.15 & $\mathrm{C}$ & C & C & C & C & C & C & C & C & C & C & C \\
\hline 39 & 0.30 & A & A & A & A & $\mathrm{M}$ & A & $\mathrm{M}$ & $\mathrm{M}$ & A & A & A & A \\
\hline
\end{tabular}




\begin{tabular}{|l|l|lllll|l|lllll|l|}
\hline 40 & -2.24 & A & A & A & A & A & A & C & C & C & C & C & C \\
41 & -4.61 & A & A & A & A & A & A & C & C & C & C & C & C \\
\hline
\end{tabular}

Note: $\mathrm{A}=$ Aggressive, $\mathrm{M}=$ Moderate, and $\mathrm{C}=$ Conservative

The working capital policy of the agro-food industry on the Stock Exchange of Thailand is shown in Table 2. According to the results, the most frequently employed working capital investment policy is the aggressive approach. This approach has been adopted by 19 companies (46.30\%). The most frequently employed working capital financing policy is the conservative approach which has been adopted by 34 companies $(82.90 \%)$. Over a 5 -year period, 13 companies (31.71\%) changed the type of working capital investment policy being used, and 16 companies (39.02\%) changed the type of working capital financing policy being used.

The three companies with highest profitability are considered to have the best practice in terms of implementing their working capital financing policy. All of those companies have mean values of moderate working capital investment policy, and 2 out of 3 companies have changed their policy from an aggressive or conservative approach to a moderate approach. With respect to working capital financing policy, all three companies have mean conservative values, and have not changed their policy in the 5-years period. Hence, the adoption of a moderate working capital investment policy and conservative working capital financing policy may possibly lead to increased profitability.

Table 3. The difference between working capital investment policy and profitability

\begin{tabular}{llllll}
\hline & Df & $\begin{array}{l}\text { Sum of } \\
\text { Squares }\end{array}$ & $\begin{array}{l}\text { Mean } \\
\text { Square }\end{array}$ & F & Sig. \\
\hline Between Groups & 2 & 346.382 & 173.191 & 5.121 & $0.011^{*}$ \\
Within Groups & 38 & 1285.169 & 33.820 & & \\
Total & 40 & 1631.552 & & \\
\hline
\end{tabular}

Note: ** Significant at $\mathrm{P}<0.01, *$ Significant at $\mathrm{P}<0.05$

Table 4. The differences of working capital investment policy

\begin{tabular}{|c|c|c|c|c|}
\hline \multirow[t]{2}{*}{ Working capital investment policy } & & Aggressive & Moderate & Conservative \\
\hline & ROA (Mean) & 5.39 & 11.73 & 9.45 \\
\hline Aggressive & 5.39 & - & $0.003^{* *}$ & 0.122 \\
\hline Moderate & 11.73 & - & - & 0.398 \\
\hline Conservative & 9.45 & - & - & - \\
\hline
\end{tabular}

Least Significant Difference: (LSD)

Note: ** Significant at $\mathrm{P}<0.01, *$ Significant at $\mathrm{P}<0.05$

According to the first hypothesis results in Table 3, the selection of different working capital investment policies has a significant effect on different profitability. Hypothesis 1 is therefore accepted $(\mathrm{P}=0.011)$. The testing of the differences between the groups shown in Table 4 shows that the difference between aggressive 
working capital investment policy and moderate working capital investment policy is significant at $\mathrm{P}<0.01$. This means that the use of a moderate working capital investment policy leads to higher average profitability $(11.73 \%)$. On the other hand, using an aggressive working capital investment policy creates the lowest average profitability, followed by the conservative working capital investment policy $(5.39 \%$ and $9.45 \%$, respectively).

Table 5. Analysis of the difference between working capital financing policy and profitability

\begin{tabular}{llllll}
\hline & Df & $\begin{array}{l}\text { Sum of } \\
\text { Squares }\end{array}$ & $\begin{array}{l}\text { Mean } \\
\text { Square }\end{array}$ & F & Sig. \\
\hline Between Groups & 2 & 41.678 & 20.839 & 0.498 & 0.612 \\
Within Groups & 38 & 1589.874 & 41.839 & & \\
Total & 40 & 1631.552 & & & \\
\hline
\end{tabular}

Note: ** Significant at $\mathrm{P}<0.01,{ }^{*}$ Significant at $\mathrm{P}<0.05$

The results of the second hypothesis in this study indicate that the selection of different working capital financing policies has a significant effect on profitability, as shown in Table 5. The actual results show that the selection of different working capital financing policies does not affect profitability $(\mathrm{P}=0.612)$. Although the test does not differ significantly, it shows that employing a conservative working capital financing policy results in higher average profitability $(8.75 \%)$, followed by aggressive and moderate policies $(8.58 \%$ and $5.34 \%$, respectively).

\section{Discussion}

Working capital policy is important to business operations because policy decisions are based on risk and profit. Different working capital policies may lead to different levels of profitability. The objective of this study is to determine three sub-policies and to test whether the selection of different working capital policies leads to an increase in profitability. Working capital investment policy and working capital financing policy are two main policies. They can also be classified into three different sub-working capital policy categories, namely: aggressive, moderate and conservative approaches. This research examines 41 companies in the agro-food industry on the Stock Exchange of Thailand. The secondary data was analyzed using a quantitative analysis between 2013 and 2017.

Policy values calculated between 0.00 to 0.40 can be classified as aggressive working capital investment policy with a conservative financing policy. A policy value between 0.60 to 1.00 can be determined as a conservative working capital investment policy and an aggressive working capital financing policy. In addition, a policy value between 0.41 to 0.59 can be determined as a moderate working capital investment policy and a moderate working capital financing policy. These results show that the most frequently employed working capital investment policy is an aggressive approach, and the most frequently employed working capital financing policy is the conservative approach.

According to the hypothesis testing, using a moderate working capital investment policy leads to the highest average profitability. In addition, this is considered to be the best practice from three companies with highest profitability. These three companies use moderate working capital investment policy. This is because an overly aggressive policy may result in insufficient current assets for the operation of a company, which may hinder profitability. On the other hand, an overly conservative policy may result in a surplus of working capital, which can impede profitability. In addition, changes in working capital financing policy have no impact on profitability. Therefore, firms listed on the Stock Exchange of Thailand in the agro-food industry 
may choose to adopt any approach (conservative, moderate, or aggressive) for their working capital financing policy.

Overall, this study demonstrates that a moderate working capital investment policy leads to an increase of profitability. This finding is inconsistent with research by Shuburi (2011), Mwangi et al. (2014) and Sudiyatno et al. (2017) which states that a company can elevate its profitability by using a conservative working capital investment policy. This is because past studies use a different relationship direction to determine the sub-investment policies. As a result, only two sub-policies can be defined, which are aggressive and conservative approaches. As this study defines the sub-policy into three categories, aggressive, conservative and moderate, the results are different. However, there is also a similarity between this study and other studies from examining working capital financing policy. This study concludes that a company can increase its profitability by adopting a conservative working capital financing policy, and the conservative approach leads to the highest average profitability $(8.75 \%)$.

\section{References}

Adam, A. M., Quansah, E., and Kawor, S. (2017). Working Capital Management Policy and Return of Listed Manufacturing Firms in Ghana. Scientific Annals of Economics and Business, 64(2), 255-269.

Brigham, E. F. and Houston, J. F. (2012). Fundamentals of Financial Management. Cengage Learning.

Hassan, W., Zubair, M., Hasnain, Z. and Hussain, S. (2017). Working Capital Management Among Listed Companies of Pakistan. International Journal of Research, 5(2), 80-91.

Hassani, M. and Tavosi, A. R. (2014). To Survey the Effect of Working Capital Policies (Investing and Financing) on Profitability Risk (Evidence from Tehran Stock Exchange). Journal of Investment Management, 3(1), 30-36.

Javid, S. and Zita, V. P. (2014). Impact of Working Capital Policy on Firm's Profitability: A Case of Pakistan Cement Industry. Research Journal of Finance and Accounting, 5(5), 182-191.

Jayarathne, T. (2014). Impact of Working Capital Management on Profitability: Evidence from Listed Companies in Sri Lanka. Paper Presented at the International Conference on Management and Economics 3, 269-274.

Koh, A., Ang, S. K., Brigham, E. F., and Ehrhardt, M. C. (2014). Financial Management: Theory and Practice. Singapore: Cengage Learning Asia Pty Ltd.

Mansoori, E. and Muhammad, J. (2012). The Effect of Working Capital Management and Firm's Profitability: Evidence from Singapore. Interdisciplinary Journal of Contemporary Research in Business, 4(5), 472-486.

Mwangi, L. W., Makau, M. S. and Kosimbei, G. (2014). Effects of Working Capital Management on Performance of Non-Financial Companies Listed in NSE, Kenya. European Journal of Business and Management, 6(11), $195-205$.

Nabi, G., Yousaf, M. S., Ali, L. and Najaf, R. (2016). Impact of Working Capital Management Approaches (Aggressive/Conservative) on the Profitability and Shareholder's Worth: Comparative Analysis of Cement and Sugar Industry. Research Journal of Finance and Accounting, 7(5), 60-65.

Nazir, M. S. and Afza, T. (2009). Impact of Aggressive Working Capital Management Policy on Firm Profitability. The IUP Journal of Applied Finance, 15(8), 19-30.

Niresh, J. A. (2012). Working Capital Management and Financial Performance of Manufacturing Sector in Sri Lanka. European Journal of Business and Management, 4(15), 23-30.

Pandey, I. M. (2000). Financial Management. India: Vikas, Publication Ltd.

Pass, C. L. and Pike, R. H. (1984). An Overview of Working Capital Management and Corporate Financing. Managerial Finance, 10(3), 1-11.

Shubiri, F. N. (2011). Determinants of Changes Dividend Behavior Policy: Evidence from the Amman Stock Exchange. Far East Journal of Psychology and Business, 4(2), 1-15.

Smith, K. (1980). Profitability Versus Liquidity Trade-offs in Working Capital Management. In: Reading on the Management of Working Capital. Smith, K. V. (Ed.). St. Paul, MN, West Publishing firm, USA, 549-562.

Sudiyatno, B. and Elen Puspitasari, S. S. (2017). Working Capital, Firm Performance, and Firm Value: An Empirical Study in Manufacturing Industry on Indonesia Stock Exchange. Economics, 5(5), 444-450.

Watson, D. and Head, A. (2010). Corporate Finance: Principles and Practice. Pearson Education.

Weinraub, H. J. and Visscher, S. (1998). Industry Practice Relating to Aggressive Conservative Working Capital Policies. Journal of Financial and Strategic Decision, 11(2), 11-18. 